\title{
A Preliminary Analysis for Measuring Operating Performance of Real Estate Investment Trusts in Taiwan: Net Income vs. Operation Funds
}

\author{
Ming-Chi Chen \\ National Sun Yat-sen University \\ E-Mail: mcchen@finance.nsysu.edu.tw \\ I-Chun Tsai \\ National University of Kaohsiung \\ E-Mail: ictsai@nuk.edu.tw \\ Kuan Liang Chen \\ PKF Taiwan \\ E-Mail: gary@pkf.com.tw \\ Henry Y. Lo \\ Nan Kai University of Technology \\ Email: ylo@ nkut.edu.tw
}

\begin{abstract}
The National Association of Real Estate Investment Trust (NAREIT) has suggested that Net Income (NI) might not be the best measure of operating performance for income-producing real estate, since depreciation measurement based on historical cost is inappropriate for income-producing real estate. Thus, the NAREIT purposes Funds From Operation (FFO) as a supplemental measure for operating performance of income-producing real estate. In Taiwan, Real Estate Investment Trusts (REITs) are a relatively new type of income-producing real estate investment. Since the data on REITs in Taiwan is not yet sufficient, this work uses hotel, tourism and department store industries, or real estate operating firms (REOCs), as a proxy for a preliminary study of REITs in Taiwan. The empirical results show that using a
\end{abstract}


model incorporating both NI and FFO understates the explanatory power of two variables, since multicollinearity occurs. Therefore, the current study separately estimates the information content of NI and FFO, finding that the explanatory power of NI is higher than that of FFO, though the forecasting ability of FFO is higher than that of NI. But the differences between the explanatory power and forecasting ability of NI and FFO are very small. The results show that NI and FFO are both informative for income-producing real estate in Taiwan.

Keywords: Net Income, Fund From Operation, Real Estate Investment Trusts

\section{INTRODUCTION}

Although real estate securitization has just started to develop in Taiwan, financial markets in various other countries have adopted it for many years. Among international financial markets, Real Estate Investment Trusts (REITs) in the United States are the most successful example of real estate securitization. The recently passed Taiwan Real Estate Securitization Act was partially structured after the U.S. REITs. REITs were established by the U.S. Congress in 1960 to allow small investors to participate in diversified, large-scale, income-producing real estate enterprises. They are corporations or business trusts managed by boards of directors or trustees. According to the National Association of Real Estate Investment Trusts (NAREIT), the number of equity REITs rose from fifty-six to 158 , and total market capitalization increased from $\$ 6.8$ billion to $\$ 134$ billion during the period from 1989 to 2000 . REITs have received increased attention in the financial literature due partially to their unique characteristics and increasing popularity among investors.

REITs are one of the few publicly traded sectors that use an alternative form of performance measurement. The main industry trade association, NAREIT has suggested that Net Income is not a meaningful measure of operating performance for income-producing real estate. With REITs, financial performance is universally determined by funds from operations, or FFO, which adds back depreciation when calculating cash flow. NAREIT claims that FFO is a better measure of operating performance because historical cost depreciation is inappropriate for income-producing real estate and does not correlate with changes in the value of these assets. Although the industry believes FFO provides better information than Net Income, the Security Exchange Committee (SEC) has historically not favored setting up unique accounting rules and measures for specific industries. Until recently, the SEC had not sanctioned FFO as a supplemental performance measurement to Net 
Income.

Real estate securitization has been an important issue in Taiwan for many years. After the Executive Yuan made the first draft of the Real Estate Securtization Act in 2002, real estate securitization has been gaining increasing attention from Taiwan's financial industry. Under the Taiwan Real Estate Securitization Act, professional real estate investment trusts purchase, manage and sell income-producing real properties and pass the rental income and capital gains on to investors. Therefore, NAREIT's assertion that FFO is a more meaningful performance measurement for income-producing real estate should apply to equity REITs or real estate operating corporations (REOCs) in Taiwan.

This paper examines the information content of the variables, Net Income and FFO, to test which one tells more about operating performance for income-producing real estate. Since data on REITs in Taiwan is still insufficient, this work uses the hotel, tourism and department store industries together as a proxy, to study REOCs for a preliminary investigation of REITs in Taiwan.

The paper structure is as follows. Section 2 describes the operating measurement of US REITs. Section 3 reviews previous studies. Section 4 discusses the methodology and empirical models this paper uses. Section 5 reports and discusses estimation results, while the last section provides a summary of the main findings and presents some conclusions.

\section{OPERATING MEASUREMENT OF US REITS}

A REIT is a company that owns, and in most cases, operates income-producing real estate such as apartments, shopping centers, offices, hotels and warehouses. Some REITs also engage in financing real estate. The shares of most REITs are freely traded, usually on a major stock exchange.

The asset structure of real estate investment trusts is composed almost entirely of fixed assets, and consequently, they are subject to a large depreciation and amortization expense. Due to this uniqueness, REITs are one of the few publicly traded sectors that use an alternative form of performance measurement. For example, NAREIT states, "most real estate industry investors have concluded that operating results for real estate companies based on historical cost accounting are misleading or uninformative." Therefore, REITs' financial performance, in addition to net income, is determined by funds from operations, or FFO, which add back depreciation and amortization expense and exclude gains or losses from sales of property to net income. NAREIT has promoted the concept of Funds From Operations as an industry-wide 
measure of REIT operating performance that does not include some items in traditional net income computed according to GAAP. Although FFO has been reported by some REITs since the early 1980's, NAREIT first provided a formal definition of FFO in 1991. In the White Paper on Funds From Operations published in April 2002, NAREIT adopted the following definition of FFO:

FUNDS FROM OPERATIONS means net income (computed according to generally accepted accounting principles), excluding gains (or losses) from sales of property, plus depreciation and amortization, after adjusting for unconsolidated partnerships and joint ventures. Adjustment calculations for unconsolidated partnerships and joint ventures reflect funds from operations on the same basis.

To promote FFO as an alternative performance measure, NAREIT argues that the income measurement model currently prescribed by GAAP does not accurately reflect the economic performance of REITs. In its published White Paper on Funds From Operations, NAREIT states that "Historical cost accounting for real estate assets implicitly assumes that the value of real estate assets diminishes predictably over time." Since real estate values rise or fall with market conditions, many industry investors consider presentations of operating results for real estate companies that use historical cost accounting as insufficient by themselves." Therefore, Funds From Operations was developed to address this problem and serve as a standard supplemental measure of operating performance that excludes historical cost depreciation on income-producing real estate from the GAAP-based net income. Furthermore, because FFO is a measure of recurring operations, GAAP's extraordinary or unusual items and significant non-recurring items should be excluded from FFO.

In 1998, NAREIT formed the Best Financial Practices Council in an effort to enhance the quality and effectiveness of industry financial practices. These industry financial practices include financial reporting and disclosure practices required by generally accepted accounting principles, as well as practices related to the industry's supplemental performance measure, Funds From Operations. The Council recommends that REITs should provide the following reconciliation in their financial statements:

The above reconciliation shows that FFO is adjusted from Net Income by adding back depreciation of real estate assets and deducting gains or losses from the sale of depreciable real estate and gains or losses from sales of other real estate and securities. The adjustments for minority interests and for unconsolidated affiliates are 
adjustments that a REIT has to make if it invests in other REITs. This is because the investor REIT might include the invested REIT's profit to which the investor REIT is entitled to as the return of investment in its financial statements. Basically, the adjustments for minority interests and for unconsolidated affiliates are made as if the invested REIT reconciled Net Income into FFO, and the investor REIT recorded the return of investment based on the investment's FFO, not Net Income.

\section{FFO/GAAP Net Income Reconciliation}

Net income attributable to common shareholders... $\$ \mathrm{x}, \mathrm{Xxx}, \mathrm{Xxx}$

Adjustments:

Depreciation of real estate assets $\mathrm{X}, \mathrm{XXX}, \mathrm{XXX}$

Gain/losses from sales of depreciable real estate ..XXX, $\mathrm{XxX}$

Gain/losses from sales of other real estate and securities. $\mathrm{XXX}, \mathrm{XXX}$ Other items:

Adjustments for minority interests $\ldots \ldots \ldots \ldots \ldots \ldots \ldots \ldots \ldots \ldots \ldots \ldots \ldots \ldots \ldots \ldots, \mathrm{xxx}$

Adjustments for unconsolidated affiliates $. \mathrm{xxx}, \mathrm{Xxx}$ FFO $\underline{\$ x, x x x, x x x}$

Weighted average shares and units:

Basic. $\underline{\mathrm{X}, \mathrm{XXX}, \mathrm{XXX}}$

Diluted... $\underline{\mathrm{X}, \mathrm{XXX}, \mathrm{XXX}}$

Source: NAREIT's National Policy Bulletin on FFO White Paper Disclosures.

One of the advantages of FFO is its treatment of depreciation and amortization expense. GAAP net income rules state that, as with factory machines and computers, depreciating assets on a historical cost basis wear out and become obsolete with the passage of time. REIT executives have argued that this type of deprecation is not "value relevant" for the type of income-producing properties that they own and operate. The buildings they own do not decline in value over time in the same manner as other types of assets. In fact, they may become more valuable over time, once location and tenancies have been established. Real estate values rise and fall, sometimes just as suddenly as the stock market. The term "FFO" was developed as a performance measure with a proper adjustment for inaccuracies associated with GAAP accounting. However, using an alternative financial measurement is obviously difficult when comparing REIT stocks with those of other companies. Since the bottom line net income is the GAAP standardized operating performance measure of all companies, it is difficult for alternative performance measures to replace net 
income. Therefore, although FFO is a widely used operating performance measurement in the REIT industry, it is not likely that FFO will replace Net Income in the future.

Traditionally, three accounting-based performance measures include: net income, cash flow from operations (CFO) and earning before interest, tax, depreciation and amortization (EBITDA). Table 1 shows the direct calculation of these performance measures from cash operating revenue and the indirect calculation of each performance measure from GAAP net income. Both earnings and CFO are required GAAP disclosures, and EBITDA, computed from audited numbers, can generally be obtained from published financial statements.

FFO is a widely used performance measure in the REIT industry. It assumes that historical cost depreciation expense is not relevant in valuing income-producing real estate. However, historical cost based depreciation expense was never intended to adjust for changes in the fair value of assets. In addition, department stores, office buildings and other real estate assets often require significant capital improvements in order to remain competitive. These capital expenditures are not all expensed; some of them may be capitalized to increase asset value. The problem of FFO is that it does not consider the effect of capitalizing these expenditures. Therefore, the empirical question is whether FFO is more value-relevant to investors than Net Income.

\section{LITERATURE REVIEW}

\section{Previous Studies on Traditional Accounting-Based Information}

In an earlier study, Ball and Brown (1968) examined the information content of cash flows using operating income as a proxy for cash flows. They found that cash flows performed poorly relative to net income and earnings per share in predicting abnormal stock returns. Although the cash flow proxy used by Ball and Brown was rather unsophisticated, their finding that the market responds more favorably to earnings than to cash flows is consistent with more recent evidence. Since the study of Ball and Brown, many other studies have been conducted based on other accounting-based information. Two recent studies include Kallunki, Martikainen and Martikainen (1998), and Dhaliwal, Subramanyam and Trezevant (1999). Of these, Kallunki, Martikainen and Martikainen (1998) use testing data from Finland to investigate which income levels and components relate to market-to-book equity ratios. The results of their empirical testing suggest that income statement items, such as sales and operating income, other than bottom-line earnings, provide useful 
information for investors. The study by Dhaliwal, Subramanyam and Trezevant (1999) evaluates which of the two performance measures, comprehensive income or net income, better summarize firm performance as reflected in stock price. Their result suggests no evidence supporting the contention that comprehensive income is more strongly associated with return or that it is better in predicting future cash flows than net income. Furthermore, the only component of comprehensive income that improves the association between income and returns is marketable securities adjustment.

For cash flows and accruals, previous studies have generally focused on two main topics. The first topic is the incremental information content of accruals over cash flows. Though accruals are subject to possible management manipulation, they may still contain information regarding future earnings and cash flows. The second topic is whether information regarding separate cash flow and accrual components of earnings has value relevance. Wilson (1986) investigates the incremental information content of accruals over cash flow for the 1981-82 period. His study updates cash flow expectations for the year-end earnings announcement and measures the cross-sectional market response to the incremental cash flow information release date using daily returns. He measures cash flow using data from the Statement of Changes in Financial Position and adjusts for current accruals in his definition of cash flows. As a result, he finds incremental informative content for cash flow and current accruals but not for non-current accruals. In his later study, Wilson (1987) investigates the extent to which cash flow and accrual components of earning contain information that is incremental to that contained in earnings alone. To test this, he uses the return reacting over a nine-day interval centered on the date at which the annual report arrives at the SEC, and defines cash flow as both working capital from operations and cash operations. The results show that cash from operations and total accruals, together, have greater ability to explain stock returns than bottom-line earnings and there is no association between working capital and stock return. By expanding Wilson (1987)'s study to thirty-two quarters, with 1976 to 1984 data, Bernard and Stober (1989) suggest that there is no evidence that the association between stock market and operating cash flow is greater than the association between stock market and current accruals. In a subsequent study, Livnat and Zarowin (1990) examine the information content of three major components of statement of cash flows. In their study, they conduct separate tests on each of the three major components - cash from operating activities, cash from investing activities and cash from financing activities. Their results suggests that cash from operations and accruals has no association with abnormal stock return and if cash from operations and cash from financing activities are regressed together, 
they are both significantly associated with abnormal returns. However, there is no evidence to show any association between cash flow from investing activities and abnormal returns.

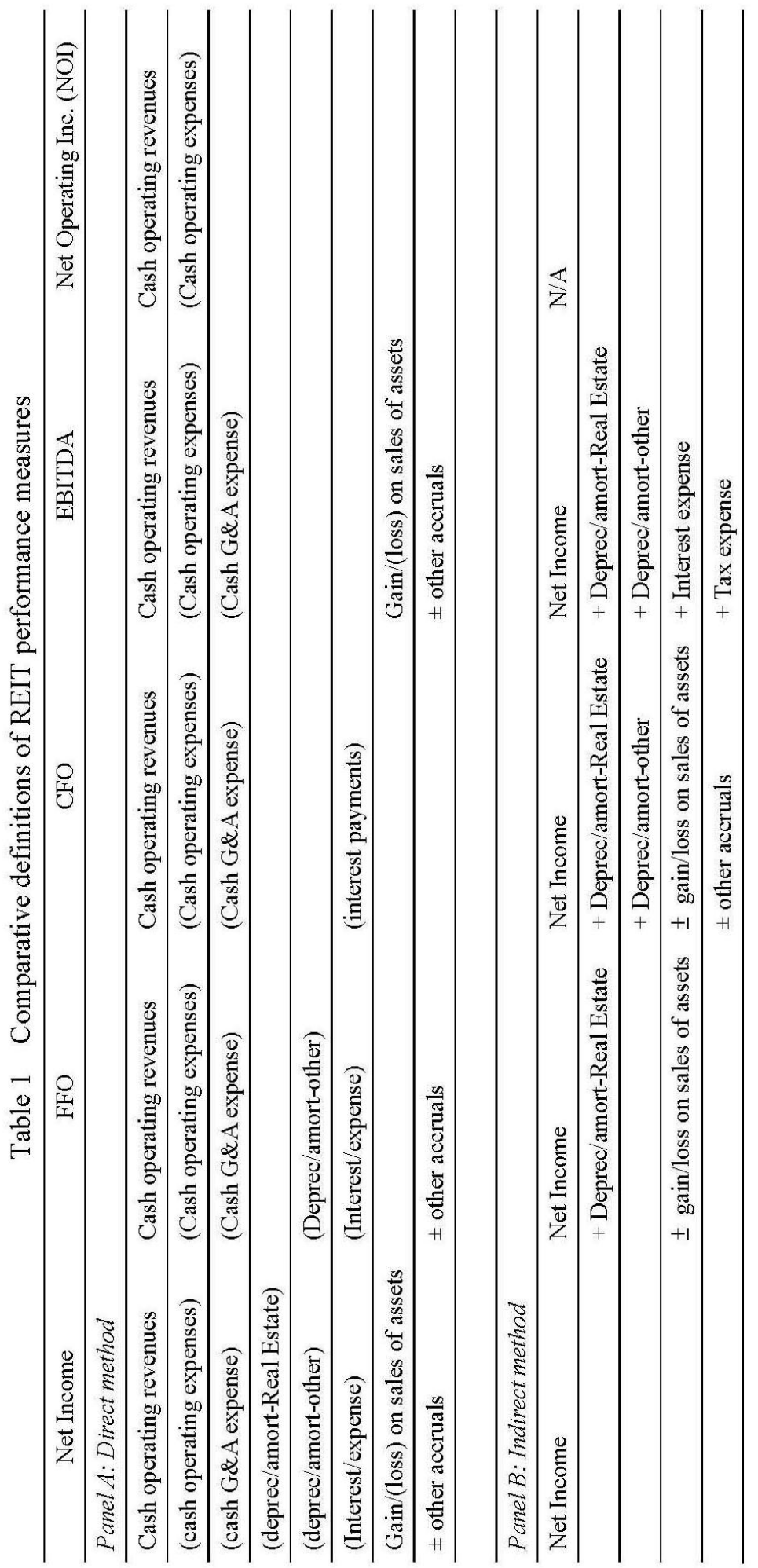




\section{Previous Studies on Funds From Operations}

The NAREIT has suggested that Net Income is a misleading measure of operating performance for the real estate industry, and this contention has led to future studies examining FFO information content. The study by Gore and Stott (1998), examines the information content of net income and FFO together with the individual components (depreciation and gain/loss from sale of properties) of net income that differ from FFO to assess their value relevance. Their finding suggests that FFO is more related to stock return than net income. They also find that gain/loss from the sale of properties is significantly associated with stock return but depreciation expense is not. Vincent (1999) compares the information content of FFO, earnings per share (EPS) and other alternative performance measures (cash from operations CFO and earnings before interest, taxes, depreciation and amortization EBITDA), using stock returns as the benchmark. The results indicate that both FFO and earnings per share provide incremental information content. The results also suggest that, with weak evidence, EPS has greater relative information content over other performance measures. According to Vincent's results, Skinner (1999) mentions that it is seemingly easy to adjust back and forth between NI and FFO based on published information, so it is not clear why investors should care which of these alternative measures are reported as the primary performance measure in financial statements. In Skinner's opinion, Vincent's study does not clearly spell out the economic argument for FFO as a superior measure of firm performance. Skinner suggests that Vincent's study use future realized measures of performance to provide a benchmark for assessing how well current period variables measure firm performance. Graham and Knight (2000) use three alternative market-based accounting research models to examine relative and incremental information content of net income and FFO. Their results are consistent with Gore and Stott (1998) in suggesting that FFO is relatively and incrementally informative in predicting stock returns. In a recent study, Stunda and Typpo (2004) examine the role that earning transitivity has on value-relevance of FFO relative to earnings. The findings indicate that as earnings become more transitive, FFO gains value-relevance, whereas earnings lose value-relevance. Additionally, both FFO and earning provide incremental information in the presence of the other.

Previous studies on cash flow are generally consistent in showing that cash flow provides valuable information content in evaluating firm performance, though studies on accrual suggest that non-current accrual items are not informative in evaluating firm performance. These findings provide support for NAREIT's claim that FFO provides relevant information for measuring real estate firm performance. Following 
NAREIT's claim, several studies have been done to determine the information relevance of FFO using REIT firm stock returns as the benchmark. Their findings are consistent in suggesting that FFO provides relevant information for evaluating firm performance. However, since NAREIT suggests that FFO performs better than Net Income in measuring operating performance of income producing real estate, a study on a traditional non-REIT real estate industry can provide useful information.

\section{METHODOLOGY}

This research uses three methodologies to capture and compare the information content of two important variables, NI and FFO, to effectively evaluate the stock value of real estate operating firms. The current work first uses panel data regression to compare the ability of the two independent variables, NI and FFO, for explaining the returns of related assets. Second, this study uses the market model to estimate the abnormal return of real estate operating firms, and tests whether or not NI and FFO are informed, for testing which variable provides more incremental information. Thirdly, this work compares the forecasting ability of NI and FFO. Conditional on the results of these three methods, this investigation completely analyzes the information content, the increment information and the forecasting ability of NI and FFO. The empirical models used in this study are simply shown as follows.

\section{Panel Data Regression}

To simply compare the ability of NI and FFO for explaining the returns of related assets, the current study uses a regression incorporated cross sectional and time series data, or panel data regression, shown in the following.

$$
R_{i, t}=a_{0}+a_{1} N I_{i, t}+a_{2} F F O_{i, t}+\varepsilon_{i, t}
$$

where $R_{i, t}$ is the $\log$ return of company $i$ on time $t, N I_{i, t}$ is the per share net income of company $i$ on time $t, F F O_{i, t}$ is the per share funds from operations of company $i$ on time $t, a_{0}$ is the constant term, $a_{1}$ is the coefficient showing the relationship between net income and the related stock return, and $a_{2}$ is the coefficient showing the relationship between operation funds and the related stock return. Following the panel data regression, this study compares the information content by observing whether $a_{1}$ or $a_{2}$ is more significantly nonzero. $\varepsilon_{i, t}$ is the error term. 


\section{The Test of Increment Information}

Although NI and FFO can be informative, the information content still needs to be analyzed to test whether or not it is incremental, since the same information might be obtained from other variables, in which case the information from NI or FFO would be useless. This investigation uses a two-step methodology to test whether or not the information of NI and FFO is increment and useful. This work first estimates the market model to obtain innovations, which are part of returns, and cannot be explained by market returns; and then separately tests the explanatory power of NI and FFO on the innovations. The models used here are shown as follows.

$$
\begin{aligned}
& R_{i, t}=b_{0}+b_{1} R_{m t}+u_{i, t} \\
& u_{i, t}=\alpha_{0}+\alpha_{1} N I_{i, t}+\delta_{1, i, t} \\
& u_{i, t}=\beta_{0}+\beta_{1} F F O_{i, t}+\delta_{2, i, t}
\end{aligned}
$$

where $R_{m t}$ is the return of the whole stock market time $t$, and other variables are defined as above. From equation 2, we find the innovations, which are the part of returns and cannot be explained by the market returns, that is $u_{i, t}$. Then this work separately tests the explanatory power of $\mathrm{NI}$ and FFO on the innovations using equation 3 and 4 . If $\alpha_{1}\left(\beta_{1}\right)$ is significantly nonzero, then there is incremental information in NI (FFO), which provides additional information for the unexpected returns. Besides, $\delta_{1, i, t}\left(\delta_{1, i, t}\right)$ is the error term in equation $3(4)$.

\section{Estimating Forecasting Ability}

Following estimating equations 3 and 4, the current study uses data from 1998Q4 to 2004Q4 to estimate the coefficients, and then uses the estimated coefficients to forecast innovations of real estate operating firms, to compare the forecasting ability of NI and FFO. The methodology is simply shown as follows.

$$
\begin{aligned}
& \hat{u}_{i, t}=\hat{\alpha}_{0}+\hat{\alpha}_{1} N I_{i, t} \\
& \hat{u}_{i, t}=\hat{\beta}_{0}+\hat{\beta}_{1} N I_{i, t}
\end{aligned}
$$

By equations 5 and equation 6 , the coefficients $\left(\alpha_{0}, \alpha_{1}, \beta_{0}\right.$ and $\left.\beta_{1}\right)$, estimated 
by the data from 1998Q4 to 2004Q4, are used to forecast the innovations from 2005Q1 to 2006Q4. Then the forecasting error, calculated by the difference between the true and the forecasting value of the innovations, can be used to calculate the statistics, Root Mean Squared Error (RMSE), Mean Absolute Error (MAE) and Mean Absolute Percent Error (MAPE), to compare the forecasting ability of NI and FFO.

\section{DATA DESCRIPTION AND EMPIRICAL RESULTS}

\section{Data}

Because hotels and department stores fit the criteria of holding and operating real estate as a primary operation, the current study draws empirical data from the hotel and department store sector of the Taiwan Stock Exchange Corporation and OTC market. The data set used in this analysis was obtained from the TEJ data bank, providing a sample of 393 observations during 1998Q4 to 2006Q4 (the 1998Q4 data is the beginning of 1999 data) for twelve publicly traded Taiwan listed firms. This study calculated the data, which cannot be found directly from TEJ, with the defined financial formulae. The definitions of variables used in this research are shown as follows.

1. Index: Taiwan Stock Exchange Capitalization Weighted Stock Index.

2. Stock Price (PRICE): Share price of sample company stocks traded in the Taiwan Stock Exchange and OTC market.

3. Earnings per Share (NI): Earnings from continuing operations before interest and taxes. This is obtained from the income statements of each sample company.

4. Depreciation Expenses per Share (DEPR): Depreciation is a cost allocation of capital assets for the periods receiving benefits from assets. This is estimated based on assets' historical price.

5. Gain/Loss from the Sale of Properties per Share (GAIN): Normally, at the end of an asset's life, the asset is sold. If the corporation has accurately projected the residual value, there is no gain or loss on the transaction. If the residual value was not estimated accurately, either a gain or a loss results from this transaction.

6. Funds from Operations per Share (FFO): FFO is a widely used operating performance measure in the REIT industry. The current research calculates FFO as follows.

\section{FFO = Net Income - Gain/Loss from the sale of properties + Depreciation Expenses}

Table 2 presents a summary of the descriptive statistics for variables, and Table 3 shows the correlation matrix of variables. 
Table 2 Descriptive Statistics of Variables

\begin{tabular}{ccccccc}
\hline Statistics & INDEX & PRICE & NI & DEPR & GAIN & FFO \\
\hline Mean & 6188.3460 & 24.5662 & 0.2550 & 0.1517 & 0.0047 & 0.4019 \\
\hline Maximize & 6139.6900 & 18.0000 & 0.1868 & 0.1044 & 0.0000 & 0.3476 \\
\hline Minimize & 9854.9500 & 191.0000 & 2.9135 & 0.5792 & 0.7233 & 2.9242 \\
\hline Std. Dev. & 3636.9400 & 5.3500 & -2.5002 & 0.0086 & -0.5515 & -2.1448 \\
\hline Skewness & 1344.5790 & 23.9703 & 0.4186 & 0.1312 & 0.0656 & 0.3944 \\
\hline Kurtosis & 0.5455 & 3.6563 & 0.7145 & 1.3623 & 4.7257 & 0.9361 \\
\hline \multirow{2}{*}{ ADF-Fisher } & 33.22 & 36.17 & 131.46 & 101.87 & 118.10 & 55.47 \\
& $(0.10)$ & $(0.07)$ & $(0.00)$ & $(0.00)$ & $(0.00)$ & $(0.00)$ \\
\hline \multirow{2}{*}{ PP -Fisher } & 28.91 & 40.46 & 209.20 & 193.40 & 243.96 & 99.11 \\
& $(0.22)$ & $(0.02)$ & $(0.00)$ & $(0.00)$ & $(0.00)$ & $(0.00)$ \\
\hline
\end{tabular}

Notes: Probabilities for Fisher tests are computed using an asymptotic Chi-square distribution. $\mathrm{P}$-values are reported in parentheses.

Table 3 Correlation Matrix of Variables

\begin{tabular}{lcccccc}
\hline Correlation & RM & RI & NI & FFO & GAIN & DEPR \\
\hline RM & 1.0000 & 0.3196 & 0.1281 & 0.1285 & 0.0241 & -0.0104 \\
\hline RI & 0.3196 & 1.0000 & 0.1510 & 0.1449 & 0.0692 & -0.0116 \\
\hline NI & 0.1281 & 0.1510 & 1.0000 & 0.9402 & 0.0844 & -0.3226 \\
\hline FFO & 0.1285 & 0.1449 & 0.9402 & 1.0000 & -0.0553 & -0.0213 \\
\hline GAIN & 0.0241 & 0.0692 & 0.0844 & -0.0553 & 1.0000 & 0.0645 \\
\hline DEPR & -0.0104 & -0.0116 & -0.3226 & -0.0213 & 0.0645 & 1.0000 \\
\hline
\end{tabular}

Table 2 also reports the outcome of tests for stationarity. This paper uses the augmented Dickey-Fuller test and the PP test. Two variables, stock market index and stock price, cannot significantly reject the null hypothesis which assumes that these variables have a unit root. To avoid the problem of spurious regression, this paper uses return data, stock market returns and individual stock return, to estimate the empirical models.

The very high correlation of 0.94 between NI and FFO, means that using these two variables in a regression may result in multicollinearity, causing indeterminate regression coefficients and infinite standard errors with misleading estimated results. Therefore, great care is essential in dealing with the problem of multicollinearity, to ensure that the results of regression incorporate both variables, NI and FFO. 


\section{Empirical Results}

\section{Panel Data Regression}

To simply compare the ability of NI and FFO for explaining the returns of related assets, this paper uses a panel data regression, with the following results.

Table 4 shows that the coefficients are all insignificant, and since the correlation between NI and FFO is very high, the results might indicate that multicollinearity is occurring. Therefore, this work revises the regression model to reduce the multicollinearity problem, and allows only one independent variable for each regression. The results are shown as follows.

Table 4 shows that the coefficients are all insignificant, and since the correlation between NI and FFO is very high, the results might indicate that multicollinearity is occurring. Therefore, this work revises the regression model to reduce the multicollinearity problem, and allows only one independent variable for each regression. The results are shown as follows.

Table 4 Results of Panel Data Regression

Model: $R_{i, t}=a_{0}+a_{1} N I_{i, t}+a_{2} F F O_{i, t}+\varepsilon_{i, t}$

\begin{tabular}{|c|c|c|c|c|}
\hline Variable & Coefficient & Std. Error & t-Statistic & P-value \\
\hline$a_{0}$ & -0.0114 & 0.0100 & -1.1391 & 0.2554 \\
\hline$a_{1}$ & 0.0343 & 0.0400 & 0.8584 & 0.3912 \\
\hline$a_{2}$ & 0.0073 & 0.0425 & 0.1713 & 0.8641 \\
\hline Adjusted R-squared & 0.0229 & AIC & & -1.5248 \\
\hline Log likelihood & 298.05 & SBC & & -1.4941 \\
\hline
\end{tabular}

Table 5 results confirm our suspicion that the coefficients of independent variables are all significant, indicating that the information of NI and FFO explains varying returns of assets. Furthermore, the results of Table 4 and Table 5 are similar to those of Graham and Knight (2000), which show the coefficients are insignificant in the model containing both NI and FFO, and the coefficients are all significant in simple regressions. 
Table 5 Results of Simple Regression

Regression 1: $R_{i, t}=a_{0}^{1}+a_{1}^{1} N I_{i, t}+\varepsilon_{i, t}^{1}$

\begin{tabular}{lcccc}
\hline Variable & Coefficient & Std. Error & t-Statistic & P-value \\
\hline$a_{0}^{1}$ & -0.0101 & 0.0067 & -1.5197 & 0.1294 \\
\hline$a_{1}^{1}$ & 0.0408 & 0.0136 & 2.9972 & 0.0029 \\
\hline Adjusted R-squared & 0.0203 & AIC & & -1.5299 \\
\hline Log likelihood & 298.04 & SBC & -1.5094 \\
\hline
\end{tabular}

Regression 2: $R_{i, t}=a_{0}^{2}+a_{1}^{2} F F O_{i, t}+\varepsilon_{i, t}^{2}$

\begin{tabular}{lcccc}
\hline Variable & Coefficient & Std. Error & t-Statistic & P-value \\
\hline$a_{0}^{2}$ & -0.0165 & 0.0081 & -2.0199 & 0.0441 \\
\hline$a_{1}^{2}$ & 0.0415 & 0.0145 & 2.8738 & 0.0043 \\
\hline Adjusted R-squared & 0.0185 & AIC & & -1.5281 \\
\hline Log likelihood & 297.68 & SBC & -1.5076 \\
\hline $\begin{array}{l}\text { Notes: where } R_{i, t} \text { is the return of company i on time t, } N I_{i, t} \text { is the per share net income of } \\
\text { company i on time t, } \\
\text { t. } F F O_{i, t} \text { is the per share funds from operations of company i on time }\end{array}$
\end{tabular}

\section{The Test of Increment Information}

Although NI and FFO are all informative in simple regressions, the information content still must be analyzed to test whether or not it is incremental, using a two-step methodology. This study first estimates the market model to obtain innovations, which are the part of returns that cannot be explained by the market returns. Then it separately tests the explanatory power of NI and FFO on the innovations. The results are as follows.

Table 6 shows that NI and FFO all significantly have incremented information, which can explain the innovations of returns. The explanatory power of NI is also higher than that of FFO, since the $\mathrm{p}$-value of $\alpha_{1}$ is higher than that of $\beta_{1}$. Moreover, the values of R-squared and log likelihood in the first regression are also higher than those of the second, although the difference between the explanatory power of NI and FFO is actually very small.

\section{Estimating Forecasting Ability}

This research uses forecasting error, calculated by the difference between the true value and the forecasting value of innovations, to calculate the statistics of Root Mean 
Squared Error (RMSE), Mean Absolute Error (MAE) and Mean Absolute Percent Error (MAPE). This compares the forecasting ability of NI and FFO, with the following results.

Table 7 shows that the forecasting ability of FFO is better than that of NI, since the forecasting errors, that is RMSE, MAE, and MAPE of FFO, are all less than that of NI, although the difference between the forecasting ability of NI and FFO here is also very small. These results indicate that NI and FFO are both informative for income-producing real estate in Taiwan. Hence, the investors of these related assets should both care the information of a company's NI and FFO.

Table 6 The Results of Increment Information Test

Step 1: $R_{i, t}=b_{0}+b_{1} R_{m t}+u_{i, t}$

\begin{tabular}{lcccc}
\hline Variable & Coefficient & Std. Error & t-Statistic & P-value \\
\hline$b_{0}$ & 0.0002 & 0.0055 & 0.0364 & 0.9709 \\
\hline$b_{1}$ & 0.5254 & 0.0794 & 6.6176 & 0.0000 \\
\hline Adjusted R-squared & 0.0998 & AIC & -1.6146 \\
\hline Log likelihood & 314.42 & SBC & -1.5941 \\
\hline
\end{tabular}

Step 2:

Regression 1: $u_{i, t}=\alpha_{0}+\alpha_{1} N I_{i, t}+\delta_{i, t}^{1}$

\begin{tabular}{lcccc}
\hline Variable & Coefficient & Std. Error & t-Statistic & P-value \\
\hline$\alpha_{0}$ & -0.0076 & 0.0064 & -1.1892 & 0.2351 \\
\hline$\alpha_{1}$ & 0.0297 & 0.0130 & 2.2946 & 0.0223 \\
\hline Adjusted R-squared & 0.0135 & AIC & -1.6282 \\
\hline Log likelihood & 317.05 & SBC & -1.6077 \\
\hline
\end{tabular}


Regression 2: $u_{i, t}=\beta_{0}+\beta_{1} F F O_{i, t}+\delta_{i, t}^{2}$

\begin{tabular}{lcccc}
\hline Variable & Coefficient & Std. Error & t-Statistic & P-value \\
\hline$\beta_{0}$ & -0.0119 & 0.0078 & -1.5413 & 0.1241 \\
\hline$\beta_{1}$ & 0.0298 & 0.0138 & 2.1633 & 0.0311 \\
\hline Adjusted R-squared & 0.0094 & AIC & -1.6267 \\
\hline Log likelihood & 316.76 & SBC & -1.6062
\end{tabular}

Notes: Where $R_{i, t}$ is the return of company $\mathrm{i}$ on time t, $R_{m t}$ is the stock market return on time $\mathrm{t}$, $N I_{i, t}$ is the per share net income of company i on time t, $F F O_{i, t}$ is the per share funds from operations of company $\mathrm{i}$ on time $\mathrm{t}$.

Table 7 The Results of the Forecasting Ability

\begin{tabular}{cccc}
\hline Statistics & RMSE & MAE & MAPE \\
\hline NI & 0.0991 & 0.0739 & 180.12 \\
\hline FFO & 0.0989 & 0.0773 & 128.23 \\
\hline
\end{tabular}

\section{CONCLUSION}

The National Association of Real Estate Investment Trust (NAREIT) has suggested that Net Income (NI) might not be the best measure of operating performance for income-producing real estate, since the depreciation measurement based on historical cost is inappropriate for this type of asset. Thus, the NAREIT purposes Funds From Operation (FFO) as a supplemental measure for operating performance of income-producing real estate. To consider this question with data from a non-western market, this work uses Real Estate Investment Trusts (REITs) in Taiwan. Since this is a relatively new type of investment, data for REITs in Taiwan is insufficient. Therefore this research uses hotel, tourism and department store industries as the proxy for a preliminary study of REITs in Taiwan.

To capture and compare the information content of two important variables, NI and FFO, to effectively examine the stock value of real estate operating firms, the current research builds three methodologies. First, panel data regression compares the ability of two independent variables, NI and FFO, for explaining the returns of related assets. Second, to test which variable has more incremental information, the market model estimates the abnormal return of real estate operating firms, and tests whether or not NI and FFO are informed. Thirdly, this work compares the forecasting ability of 
NI and FFO. Based on the results of these three methods, we thoroughly analyze information content, incremental information and forecasting ability of NI and FFO.

The empirical results show that using a model incorporating both NI and FFO, understates the explanatory power of two variables since multicollinearity occurs. Therefore, we separately estimate the information content of NI and FFO, finding that the explanatory power of NI is higher than that of FFO, though the forecasting ability of FFO is higher than that of NI. However, the differences between the explanatory power and forecasting ability of NI and FFO are very small. These results indicate that NI and FFO are both informative for income-producing real estate in Taiwan. Hence, the investors of these related assets should consider the information of a company's NI and FFO. This research did not account for transitory earnings into FFO due to no transitory earnings data available in Taiwan. Future research should consider this aspect since the explanatory power of FFO may be greater when considering the data of transitory earnings.

\section{REFERENCES}

Ball, R., \& Brown, P. (1968). An empirical evaluation of accounting income numbers. Journal of Accounting Research, 6(2), 159-178.

Bernard, V. L., \& Stober, T. L. (1989). The nature and amount of information reflected in cash flows and accruals. The Accounting Review, 62(4), 624-652.

Dhaliwal, D., Subramanyam, K. R., \& Trezevant, R. (1999). Is comprehensive income superior to net income as a measure of firm performance. Journal of Accounting and Economics, 26(1-3), 43-67.

Gore, R., \& Stott, D. M. (1998). Toward a more informative measure of operating performance in the REIT industry: net income vs. funds from operations. Accounting Horizons, 12(4), 323-339.

Graham, C. M., \& Knight, J. R. (2000). Cash flows vs. earnings in the valuation of equity REITs. Journal of Real Estate Portfolio Management, 6(1), 17-25.

Kallunki, J. P., Martikainen, M., \& Martikaninen, T. (1998). Accounting income, income components and market-to book equity ratios: finnish evidence. The International Journal of Accounting, 33(3), 359-375.

Livnat, J., \& Zarowin, P. (1990). The incremental information content of cash flow components. Journal of Accounting and Economics, 13(1), 25-46.

NAREIT (2002). NAREIT white paper on funds from operations (National Association of Real Estate Investment Trusts). Washington, D. C.: NAREIT, Inc. 
Skinner, D. J. (1999). How well does net income measure firm performance? A discussion of two studies. Journal of Accounting and Economics, 26(1-3), 105-111.

Stunda, R. A., \& Typpo, E. (2004). The relevance of earnings and funds flow from operations in the presence of transitory earnings. Journal of Real Estate Portfolio Management, 10(1), 37-45.

Vincent, L. (1999). The information content of funds from operations (FFO) for Real Estate Investment Trusts (REITs). Journal of Accounting and Economics, 26(1-3), 69-104.

Wilson, G. P. (1986). The relative information content of accruals and cash flows: combined evidence at the earnings announcement and annual report release date. Journal of Accounting Research, 24(3), 165-203.

Wilson, G. P. (1987). The incremental information content of the accruals and funds components of earning after controlling for earnings. The Accounting Review, 62(2), 293-322. 
APPENDIX: LIST OF SAMPLE COMPANIES

\begin{tabular}{lll}
\hline Code & \multicolumn{1}{c}{ Company Name in English } & \multicolumn{1}{c}{ Market of Listing } \\
\hline 2701 & WANHWA ENTERPRISE COMPANY & Taiwan Stock Exchange \\
\hline 2702 & HOTEL HOLIDAY GARDEN & Taiwan Stock Exchange \\
\hline 2704 & THE AMBASSADOR HOTEL, LTD. & Taiwan Stock Exchange \\
\hline 2705 & THE LEOFOO DEVELOPMENT CO., LTD. & Taiwan Stock Exchange \\
\hline 2706 & FIRST HOTEL COMPANY LTD. & Taiwan Stock Exchange \\
\hline 2707 & FORMOSA INTERNATIONAL HOTELS & Taiwan Stock Exchange \\
\hline 5701 & JANFUSUN FANCY WORLD & OTC \\
\hline 5703 & THE LANDIS TAIPEI HOTEL CO., LTD & OTC \\
\hline 5704 & HOTEL ROYAL CHIHPEN & OTC \\
\hline 2901 & SHIN SHIN CO LTD. & Taiwan Stock Exchange \\
\hline 2903 & FAR EASTERN DEPARTMENT STORES LTD. & Taiwan Stock Exchange \\
\hline 2910 & TONLIN DEPARTMENT STORE CO.,LTD. & Taiwan Stock Exchange \\
\hline
\end{tabular}

